Izvorni znanstveni rad DOI: $10.17234 /$ Croatica.41.16

UDK: 821.163.42-13.09"17"

\title{
SLAVONSKA VERZIJA SPJEVA O FILOMENI IZ 1786. GODINE
}

\author{
Milovan Tatarin \\ Filozofski fakultet Sveučilišta Josipa Jurja Strossmayera u Osijeku \\ mtatarin@knjiga.ffos.hr
}

U Novom i starom svetodaniku iliti kalendaru iliričkom za 1786. godinu kao jedini književni prilog tiskan je spjev Izkazanje od Filomene, kćeri kralja Pandijana. Riječ je o priči o Filomeli, Progni i Tereju što ju je Ovidije ispripovijedao u šestom pjevanju Metamorfoza. Priređivaču je kao predložak poslužila Historija od Filomene, héere kralja Pandijana fra Ivana od Zadra: čakavski je tekst prenio u štokavsku ikavicu, mnoge je dijelove izostavio, neke je sažeo, neke izmijenio, a kadšto je dodavao nove stihove.

Ključne riječi: slavonska književnost 18. stoljeća, kalendar, Ovidije, Filomena, Ivan Zadranin, Marijan Lanosović

Znali su slavonski pisci 18. stoljeća kadšto posegnuti za djelima iz južnih hrvatskih regija pa ih ponašiti, "od nikih riči, u ovima stranama, kod Ilira neobičajnih, očistiti", kako je to svojedobno kazao Ivan Velikanović (1723-1803), priređujući Muku Gospodina našega Isukrsta Petra Kneževića (1702-1768), objavljenu prvi put 1753. u venecijanskoj Occhievoj tiskari. Muku Gospodina našega Isukrsta i plač Divice Marije, majke njegove 
najprije je tiskao u knjizi Razmišljanja bogoljubna svetoga Bonaventure (Osijek, 1776, str. 135-206), a potom iste godine kao samostalnu knjigu u tiskari Ivana Martina Divalta (1743-1806). Antun Josip Knezović († 1764) priredio je po danas nepoznatom mletačkom izdanju iz 1698. Život svete Olive, napominjući u Prikazanju dragoljubnom domorodcu da je spjev iz "hrvackoga u naški sabrao", što znači da ga je premetnuo iz čakavštine u štokavsku ikavicu: "Može bit u Mleci da se može nać, / al se daje za knjige sad veliki harač. / Prem ako bi i mogli odonud imati / mučno je jezika onog razumiti, / zato ga postavi slavinskim jezikom / da ne tražiš jabuku pod tuđim stablom" (Tatarin 2007: 114). Knezović je spjev objavio u Pešti 1761, a da je knjiga bila popularna, potvrđuje podatak da se sačuvala - koliko se danas zna - u samo jednom primjerku (Tatarin 2007: 108-109). Ignjat Alojzije Brlić (1795-1855) poslavončio je Kristijadu Junija Palmotića (1607-1657), koja je pod naslovom Krstovka 1835. izišla u Budimu (Pavličić 1998: 172-192), a mijenjao je i sastavke dubrovačko-dalmatinskih pisaca, koje je unosio u svoj Novouređeni ilirski kalendar iliti svetodanik (Radonja Vladislava Menčetića /oko 1617-1666/, Od privare i zle naravi ženske Ivana Ivaniševića /1608-?1665/, Anka i Stanko Ane Vidović /1799-1879/). ${ }^{1}$

Priču o Filomeli (Filomeni), Progni (Prokni) i Tereju ispripovijedao je Ovidije (43. pr. n. e. - 18. n. e.) u šestom pjevanju Metamorfoza (s. 412-674), a započeo ju je trenutkom kad predstavnici različitih gradova idu tješiti Pelopsa, sina lidijskoga kralja Tantala, kojega je otac ubio, raskomadao i prinio bogovima kao hranu želeći vidjeti hoće li prepoznati što im je ponudio. Bogovi su Tantala kaznili, a Pelopsa oživili. Oko Pelopsa su se okupili svi, tek nitko nije došao iz Atene koju su napali barbari, a porazio ih je trački kralj Terej, zbog čega mu je atenski kralj Pandijan dao kćer Prognu za ženu. Nakon pet godina - u međuvremenu su Progna i Terej dobili sina Itisa Progna poželi vidjeti sestru Filomelu. Terej ode po nju, a kako ga je očarala njezina ljepota, prije povratka na dvor ju siluje i odreže joj jezik. Progni pak kaže da joj je sestra putem umrla. Zatvorena i pod stražom, Filomela se ipak dosjetila kako obavijestiti sestru: na bijeloj je tkanini grimiznim koncem navezla što joj je Terej učinio. Kad Progna pročita pismo, užasne se, ali ništa ne govori Tereju, nego u noći Bakhovih svečanosti pronađe Filomelu i dovedu je kući. Promatrajući koliko je Itis sličan ocu, zajedno s Filomelom ubije dječaka kojega potom raskomadaju, neke dijelove skuhaju, neke ispeku

Pisao sam o Brlićevim kalendarima u Tatarin 2006: 107-141. 
pa posluže Tereju za jelo. ${ }^{2}$ Kad Terej zaište da mu dovedu sina, Progna mu kaže: "Koga tražiš, u sebi imadeš ga!", a uto dolazi Filomela noseći krvavu Itisovu glavu koju baci na Tereja. Sasvim izbezumljen potrči za ženama hoteći ih posjeći mačem, no bogovi ih pretvore u ptice - jedna poleti u šumu (Filomela), druga se sakrije pod krov (Progna) - a Tereja preobraze u pupavca.

Metamorfoza o Filomeli ne pripada među priče kojima su se dopreporodni hrvatski pisci češće vraćali. Njezin je sadržaj u stihovima obrađen samo jedanput, u spjevu Historija od Filomene, hćere kralja Pandijana fra Ivana od Zadra (Kolumbić 2005: 102). Kad je prvi put objavljen, nije utvrđeno, a u literaturi se navode različita izdanja, od 1650. do 1772, koje autori nisu vidjeli nego ih spominju po sekundarnim izvorima. U međuvremenu se pojavio rad Aleksandra Stipčevića o inventaru iz 1678, u kojemu su pobilježene knjige koje su se zatekle što u knjižari, što u kući Francesca Brogiollia. Riječ je o venecijanskom tiskaru u čije je vlasništvo oko 1668. prešla tiskara i sve knjige tvrtke Ginammi, a nakon Brogiollieve smrti 1678. tiskara i knjige prešle su u vlasništvo Bartolomea Occhia. Među knjigama nalazila se i Historija od Filomene, u prilično velikom broju: 870 primjeraka u Brogiollievoj knjižari i 130 primjeraka u kući. Važna je Stipčevićeva napomena da Historija od Filomene

svakako je tiskana prije 1633. god. kada se spominje u popisu hrvatskih knjiga Marca Ginammia tiskanom u knjizi A. Komulovića Zarçalo [...], i to pod naslovom Filomena Istoria [...]. Knjižicu je za tisak priredio fra Ivan Zadranin, no malo je vjerojatno da je on bio i priređivač izdanja koje se spominje u Ginammievu popisu iz 1633. god. Brogiolli je očigledno imao na prodaju svoje izdanje te knjižice, no nije ga uspio raspačati, pa je ostatak njegove naklade dospio u knjižaru B. Occhia kako to pokazuju njegovi prodajni popisi tiskani od 1700. do 1702 . Spominje se Historia od Filomene i u kasnijim Occhievim prodajnim popisima, no tada je reklamirao svoje vlastito izdanje iz 1702. godine. (Stipčević 2008: 285)

Dok se netko ne poduhvati prosudbe toga pitanja, zadovoljit ću se onim što je provjerljivo: u Nacionalnoj i sveučilišnoj knjižnici u Zagrebu čuvaju se venecijanska izdanja iz 1672. (R II C - 16º - 64) i 1702. (R II C $\left.-16^{\circ}-158\right)$. Prvo je objavio Brogiolli, drugo Occhi, a po starijem je Amir

2 Filicid nije nepoznat antičkom mitu: Heraklo je u ludilu ubio trojicu sinova, a Medeja - da se osveti Jazonu - dvojicu. 
Kapetanović priredio kritičko izdanje (2004: 277-309) te iscrpno opisao njegove jezične osobine (2003: 131-155). Osim njih u knjižnici Hrvatske akademije znanosti i umjetnosti pod signaturom $\mathrm{R}$ - 251 sačuvana su dva primjerka u privezu, no oba su manje ili više oštećena.

Tko je bio franjevac Ivan, koji je spjev "dao na svitlost”, je li on bio autor ili samo priređivač, mogu li mu se pripisati još koji tekstovi pitanja su koja su književni povjesničari pretresali više puta (Kapetanović 2004: 280-283). Franjo Švelec (1994: 135) optirao je za Barnu Karnarutića (između 1515. i 1520-?1573), a u katalogu Nacionalne i sveučilišne knjižnice spjev je danas iz nekoga razloga upisan pod imenom Ivana Tanzlingera Zanottia (1651-1732). Amir Kapetanović je upozorio na jezičnostilske sličnosti između Historije od Filomene te Vazetja Sigeta grada (Venecija, 1584) i Izvarsite ljubavi i napokon nemile i nesrićne smarti Pirama i Tižbe (Venecija, 1586), no nije odlučno ustvrdio da imaju snagu dokaza u korist Karnarutićeva autorstva (2004: 282-283). Nikakve veze s Historijom od Filomene nema tragedija Filomena, nastala po motivima adespotne šesnaestostoljetne talijanske novele Istoria dell' infelice innamoramento di Gianfiore e Filomena. Sadržaj joj je prepričao Mirko Deanović (1912: 688-696), izvor odredio Petar Kolendić (1964: 203-207), objavio ju je Josip Lisac (2015: 79-120), a kad je o autoru riječ, tražilo ga se među Gundulićima: bilo je mišljenja da je Filomenu ispjevao Ivan Gundulić (1589-1638), Deanović je razmišljao o njegovu sinu Šišku (1634-1682), Kolendić je pak bio skloniji unuku Ivanu (1678-1721), pa je tako ostalo do danas.

Po tematsko-motivskim, žanrovskim, versifikacijskim, uopće poetičkim osobinama Historija od Filomene nalik je Životu svete Olive, spjevu koji je mnogo puta tiskan $(1702,1722,1841,1851,1878,1889$, 1908), uvijek anonimno (Tatarin 1999: 132-188). To je vrsta štiva niskoga estetičkog dosega, koje je popularnost među pismenim "prostim pukom" steklo zahvaljujući bizarnim, pa i perverznim fabulama, u kojima vladaju incestuozni seksualni porivi, sakate se tijela, likovi su izloženi neizdrživim mukama zapadajući pritom u ekstremna emocionalna stanja. Tko god da je ta djela pisao, nije se trudio oko, općenito kazano, literarnosti, važnije od svega bilo je ispripovijedati u kompozicijskom i stilskom smislu jednostavnu priču koja će izazvati ponajprije zgroženost i sažaljenje. Doista, utvrđujući ovisnost Historije od Filomene o Ovidiju, pobrajajući neka odstupanja od predloška

3 To ću izdanje koristiti u ovom radu. 
(izostavljanje priče o Pelopsu, Terej u spjevu Filomenu ne odvodi u "visoki tor" nego "štalu", Filomena sestri izvezenu tkaninu ne šalje po nekom "čovjeku" nego "divici", Ovidije ne navodi u koju su se ptice pretvorile Progna i Filomena, a uopće ne spominje preobrazbu Prognina sina Itisa), David Bogdanović - prvi koji je o spjevu "analitičkije" pisao - istaknuo je sljedeće: "I evo tako, držeći se u glavnome Ovidija, nastavlja fra Ivan od Zadra dalje svoju historiju od Filomene sad raširujući pripovijedanje sad ga ponešto skraćujući, razvodnjujući najljepša Ovidijeva mjesta, bez osjećaja za pravu ljepotu i bez pravoga razumijevanja za najljepše situacije i psihološke momente u Ovidijevoj pjesmi i bez težnje za efektom, za kojim Ovidije često ide" (1928a: 66). ${ }^{4}$

U slavonske kalendare 18. i prve polovice 19. stoljeća unosili su njihovi priređivači različite tekstove: trajno je popularan bio Razgovor ugodni naroda slovinskoga (Venecija, 1756, prošireno izdanje 1759) Andrije Kačića Miošića (1704-1760), zatim stihovane Ezopove i ezopovske basne, kadšto se po kalendarima nađe poučnih pričica iz zbirke Nek je svašta (Osijek, 1795) Matije Antuna Relkovića (1732-1798), mnoštvo kratkih i duhovitih "pripovidaka i dositaka", pjesama o ženskoj ćudi, modi i pomodarskim običajima, a najraznovrsnije su štivo sadržavali kalendari Ignjata Alojzija Brlića, koji je češće objavljivao djela južnohrvatskih pisaca, zatim dijelove iz Nadodanja glavni događaja Razgovoru ugodnomu naroda slovinskoga (Pešta, 1768) Emerika Pavića (1716-1780), pregršt basana iz knjige Fedra, Augustova odsužnjika, pričice Esopove (Dubrovnik, 1813) Đura Ferića (1739-1820) itd. Među Slavoncima, Ovidijem se najviše bavio Antun Nagy (1774-1847), prepjevavajući Tristije i Metamorfoze, premda ni jedan ni drugi prepjev nije uspio objaviti, tek je u svom Novom i starom kalendaru iliričkom za 1813. godinu tiskao "priobraznu pismu" o Piramu i Tizbi (Iz IV. Priobrazne knjige Publije Ovidije Nasona pisma II.) (Tatarin 2006b: 87-111), a u kalendaru za 1814. godinu jednu "žalostnicu" (Plačnopjevka treća iz prve knjige Žalostnicâ Publije Ovidije Nazona u kojoj žalostni iz varoša Rima odlazak izpisuje). Žalostnice je uzaludno 1835. nudio Ljudevitu Gaju za Danicu, a prepjev Metamorfoza stradao je u poplavi Dunava 15. ožujka 1838.

4 Neovisno o Bogdanovićevu radu iste je godine objavljen tekst Rijetka knjiga: Ovidijeva metamorfoza u hrvatskoj preradi g. 1602., koji je potpisao J. B-ć i objavio u "Književniku". Potpisnik je u rukama nedvojbeno imao Occhievo izdanje iz 1702, kojemu je na naslovnici pogrešno otisnuta 1602. godina. 
Premda nisu znali da je riječ o Ovidiju, mogli su Slavonci i prije Nagyevih prepjeva pročitati nešto iz njegove bogate riznice - spjev naslovljen Izkazanje od Filomene, kćeri kralja Pandijana, tiskan u kalendaru za 1786. godinu:

NOVI I STARI | SVETODANIK | ILLITI | KALENDAR | ILLYRICSKI | ZA | PRISTUPNO GODISHTE I 1786. I NA I KORIST I ZABAVU SLOVINACAH | SLOXEN. I Cum Privil. S. C. R. Apot. Majet. ${ }^{5}$ I U BUDIMU, I Slovima Katarine Landererove udovice. ${ }^{6}$

Nije ta obrada sasvim nepoznata u hrvatskom književnopovijesnom studiju: znala je za nju Divna Zečević navodeći ju u kontekstu tipičnih pučkih motiva koji su prešli u usmenu predaju, a i zato što reprezentira "glad za događajima koji predstavljaju maksimalni otklon od prirodnog i koncipiranog reda" (Bošković-Stuli i Zečević 1978: 483). Osim nje, spjevom se nitko nije bavio, tek ga je u radu o Historiji od Filomene Ivana Zadranina spomenuo Amir Kapetanović, no iz nekoga je razloga govorio o kajkavskom kalendaru i kajkavskoj obradi (2004: 279, bilješka 4).

\section{II.}

Izkazanje od Filomene jedini je književni sastavak u kalendaru za 1786. godinu, a nakon čitanja postaje jasno da nije riječ o samostalnoj obradi Ovidijeve metamorfoze, nego da je slavonski priređivač nedvojbeno pred sobom imao tiskano izdanje Historije od Filomene. ${ }^{7}$ U naslovu je "historiju" zamijenio među slavonskim piscima uobičajenijom riječju "izkazanje", 8 ime Ivana Zadranina nije naveo, no to nije neočekivano kad je o kalendarskom štivu riječ. Razlikuje se kalendarska verzija i po duljini: Historija ima 787,

5 Cum Privil(egio) S(acra) C(aesarea) R(egiaque) Apost(olica) Majest(as) = S dopuštenjem Svetoga Carskoga i Kraljevskoga Apostolskog Veličanstva.

6 Crvenom je bojom otisnuto sljedeće: SVETODANIK, KALENDAR, 1786., Cum Privil. S. C. R. Apot. Majet., U BUDIMU. Kalendar se čuva u osječkom Muzeju Slavonije.

7 Historiju od Filomene danas ne posjeduje nijedna franjevačka knjižnica (Frkin i Holzleitner 2008).

8 U Akademijinu Rječniku navedeni su primjeri iz Kamena pravog smutnje velike (Osijek, 1780) Antuna Kanižlića (1699-1777), treće knjige Upućenja katoličanskih (Osijek, 1788) Ivana Velikanovića (1723-1803) te Života Petra Velikoga, cara Rusije (Osijek, 1794) Aleksandra Tomikovića (1743-1829). Rječnik hrvatskoga ili srpskoga jezika, dio III: str. 879. 
a Izkazanje 504 dvanaesterca (283 stiha manje). Završnih pet stihova Historije, u kojima se spominje Ivan od Zadra, također je izostavljeno. ${ }^{9}$ Da je slavonski priređivač preradio čakavski spjev, vidi se, među ostalim, i po dijelu u kojemu je riječ o preobrazbama glavnih likova u ptice. Odavna je naime David Bogdanović upozorio da

Ovidije, osim Tereja, nigdje ne kaže, u kakve su ptice pretvorene obadvije sestre, nego se tek možemo domisliti da je Progna pretvorena u lastavicu ('subit tecta') a Filomela u slavuja ('petit silvas'), dok za Terejeva sina Ovidije ne kaže, da bi bio u što pretvoren, a kamoli u 'fazana' gospodina 'jistinom najveć poglavitom', kako to hoće naš fratar s pobožnom motivacijom (1928a: 68).

Upravo je tako i u slavonskoj verziji, dapače, i ovdje je Tereo - u Ovidija preobražen u pupavca - postao "petelin" (pijetao), premda opis ne odgovara toj ptici: "Dug kljun kano mača dugoga još znate" (s. 484). Bit će da je riječ o prilagodbi uvjetovanoj stvarnošću: svi su čitatelji znali što je pijetao, a samo rijetki što je pupavac ili futač (lat. Upupa epops). Inače, nema tragova koji bi upućivali da je slavonski priređivač uz čakavski spjev koristio i Ovidijev izvornik; što je mimoišao pisac Historije od Filomene osobito razvijene Ovidijeve usporedbe - mimoišao je i pisac Izkazanja, ispustivši pritom još mnoge detalje. U literarnom smislu, to su više nego skromna djela.

Konverzija čakavskog teksta u štokavsku ikavicu povukla je za sobom mnoge promjene, jer nije riječ samo o tome da se jedna riječ zamijeni drugom, slavonskom čitatelju razumljivijom; priređivač je morao mijenjati konstrukciju retka, što je utjecalo na ritam i rimu. Može se reći da su iznimno rijetki stihovi koji u kalendarskoj verziji nisu pretrpjeli izmjenu, točnije, samo je dvanaest identičnih stihova. Navodim početak spjeva iz kojega se dobro vidi kako je slavonski priređivač postupao s predloškom:

\section{Historija}

Budući Pandijan kraljem od Atene,

Lipe Pronje otac tere Filomene,

Tereo kralj zemlje drinopoljske biše,

Ki se ujistinu ženiti hotiše,

9 "Svaršena istorija lipe Filomene, / Ku fra Ivan Zadra da na svitlo, znaj. / Ki štiš, Bogu zato hvalu i slavu daj, / A za mene moli ga da me prime k sebi, / Tako t' ta historija utišen'je tebi”, s. 783-787 (Kapetanović 2004: 308). 
Zato h Pandijanu posla hćer pitati

Da bi mu Pronju htil za ženu podati.

Pandijan kralj reče: "Hoću dobre volje

Jer sam tomu kuntent i vesel dovolje."

Tereo naarma galije i navi,

Vitezi dovolje ter vladik odpravi

Da Pronju jimaju pojti rukovati

Ter ju za kraljicu njemu dopeljati.

I tako s veseljem velikim jidoše,

Doma opet tukoj nazada pridoše. (s. 1-14)

\section{Izkazanje}

Prislavne Pandijan kralj bî od Atene,

krasne Progne otac, lipe Filomene,

Tereo kralj zemlje sridnopoljske biše,

koji se zaisto ženiti hotiše.

Zato Pandijana on posla pitati

da bi htio Prognu za ženu podati.

Pandijan mu bijelu udilj knjigu šalje:

"Ja sam zadovoljan, već ne traži dalje".

Tereo tad lađe spravi i galije,

viteze dovolje i mlade delije. (s. 1-10)

I letimičan pogled otkriva da slavonska verzija nije nastala zamjenom jednog leksema drugim, nego je priređivač prepjevao predložak, gotovo onako kako se to čini kad se tekst prenosi iz jednog jezika u drugi. Pritom je često izostavljao dijelove spjeva (u gornjem primjeru to su stihovi 11-14), zatim ih je sažimao i mijenjao (primjerice stihove 7-8 Slavonac je preoblikovao služeći se i formulama usmene književnosti: "bijela knjiga", "mlade delije", a potkraj spjeva upotrijebit će riječ "babajko" umjesto otac), kadšto je premještao dijelove predloška te dodavao stihove kojih u predlošku nema. Samo je na dva mjesta zadržao riječi iz predloška stavljajući u zagradu objašnjenje: "dresela" = tužna, "droban" = malen:

\section{Historija}

Požgi mu sve gradi i kuće i sela,

Oboj budi meni, jer ti sam dresela! (s. 253-254)

Zač Hitis budući mlajahan i droban

K svomu ocu kralju vas biše podoban (s. 543-544) 


\section{Izkazanje}

Požgi mu sve kuće, gradove i sela, oboj budi meni jer ti sam dresela! (s. 159-160)

jer Hitis bijaše mlađanin i droban, svomu otcu kralju vs biše podoban (s. 349-350)

Budući da je mnoge stihove izostavio, priređivač je ponekad ubacivao svoje stihove da bi povezao dijelove spjeva. Primjerice skrativši Terejev i Prognin razgovor u kojemu ga ona moli "da joj od dvih jednu on milost učini” (s. 31), umetnuo je Slavonac vezni stih:

\section{Historija}

Reče: "Gospodine, to znaj da ja venu

Želeći sestricu moju Filomenu.

Ili me pusti $\mathrm{k}$ njoj da ja mogu pojti

Ali ona k meni da more sad dojti." (s. 41-44)

\section{Izkazanje}

Svojega moliti poče gospodina:

"Tako ti mlađanog Hitis, tvoga sina,

ja te, kralje, molim, učini mi što prosim.

Filomenu sestru viditi ja želim;

ili me k njoj pusti da ja mogu pojti,

ili ona k meni da može sad dojti”. (s. 21-26)

Obećavajući Pandijanu da će mu Filomenu vratiti živu i zdravu, Tereo kaže:

Tereo se bozim svojima ja kleti:

"Hoću ti ju dovesti kad budeš hotiti,

Listo Pronji želja da bude na mesti,

Ja ću t' Filomenu životom dovesti." (s. 123-126)

\section{U Izkazanju je to rečeno ovako:}

Tereo se bozim svojim poče kleti:

"Hoću ju dovesti kad budeš hotiti,

samo Progni želja da bude na misti, tako t’ bogov naši i božicâ isti!" (s. 83-86) 
Nakon što Tereo isplovi iz Pandijanova kraljevstva, postaje sve nestrpljiviji i jedva se suzdržava da Filomenu ne oskvrne na brodu:

Zalu volju svoju spuniti hoteći,

Poganin nečisti goraše želeći.

Za tuko veselje ne znaše ča čini:

Filomenu videć daleč u pučini,

Kine obraz an' jelski očima zoreći,

Da volju izpuni jedva se daržeći. (s. 201-206)

U Izkazanju priređivač dva stiha ispušta (s. 203-204), a jedan sadržajno mijenja:

Zalu volju svoju izpunit hoteći, poganin nečisti, goraše želeći,

vs mu planti obraz, očima zoreći

da volju izpuni jedva se držeći. (s. 115-118)

Takvih primjera ima dosta, a premda vrlo rijetko, Slavonac zna popraviti rimu predloška:

\section{Historija}

"To li je vira tva, tim li se obeća

Kralju Pandijanu kad jide od njega?" (s. 238-239)

\section{Izkazanje}

To li tvoja vira, tim li se obeća

kralju Pandijanu, oh, tugo najveća! (s. 143-144)

\section{Historija}

I tako budući minulo deset let,

Filomena zbudi svoju tanku pamet

Jere po svaki put ča godi hotiše,

Rukami svojimi činiti umiše.

Tako i postavi krosna tanke svile,

Zlatom ja pisati uzrok svoje sile.

Sve ča sama htiše, napisa umiće,

Svu tugu ter žalost nje vele nesriće. (s. 385-392) 


\section{Izkazanje}

Posli lita deset, jer vesti umiše, domisli se sestri svaka da upiše,

tako i odsiče komad tanke svile, zlatom ter upisa uzrok svoje sile,

kako ona jako silovana biše, kako u pustinji jezik izgubiše. (s. 257-262)

\section{Historija}

A sad je u meču sve moje ufan'je,

Da platim Tereja za njega činjen'je.

Sarce moje nigdar ne će biti sito

Raspa $i$ žalosti, to znaj stanovito. (s. 521-524)

\section{Izkazanje}

A sad je u maču sve moje ufanje da platim Tereja za njega činjenje,

srce moje nigdar hoće biti sito dok ne vidim njega mrtva stanovito. (s. 335-338)

\section{Historija}

Da neka da znate da na t' blagdan Bakov

Biše v 'no vrime svude zakon takov:

Da nigdor nego muž ženom jima jisti

Ni k njom u komoru nigdor ne ulisti. (s. 637-640)

\section{Izkazanje}

Kada dojde vrime za večeru sisti, tad ode kraljica večeru donesti.

Neka pak zna svaki da na blagdan Bakov biše u 'no vrime svude zakon takov

da niko neg muž sa ženom sidjaše,

nit k njim u komoru itko idjaše. (s. 393-398)

\section{Historija}

Fazanom stvoriše željnoga kraljića,

Koga mati ubi, tužnoga ditića, Zač on biše bil plemenito rojen,

Prez svake krivine svoje buduć ubijen, 
Zato ga stvoriše pticom plemenitom.

Gospodin jistinom najveć poglavitom. (s. 767-772)

\section{Izkazanje}

Fasanom stvoriše željnoga kraljića,

koga mati ubi tužnoga ditića,

i jer on bijaše plemenito rođen,

brez svake krivice kuhan još i pečen,

zato ga stvoriše pticom plemenitom

koja se cesaru nosi poglavitom. (s. 489-494)

\section{Historija}

Ova historija na vaše pošten'je

V kratku govoren' ju sad jima svaršen'je. (s. 781-782)

\section{Izkazanje}

Ovo izkazanje na vaše poštenje, štioci, pričastno sad ima svršenje. (s. 503-504)

Kako je rečeno, slavonski je priređivač spjev uskladio s jezičnim navikama svoje sredine, no ponekad je intervenirao u čakavske stihove ne zato što bi koja riječ slavonskim čitateljima bila nerazumljiva, nego zacijelo zato jer mu se činilo da je njegov izbor na neki način prikladniji, kontekstualno točniji, a možda i - slikovito kazano - ljepši:

\section{Historija}

Jošće se hudi pas na nju ne smilova,

Tako naruženu jošće ju silova.

A pak ju napokon u pustinji ostavi

Ter stražu veliku nad njom on postavi,

Ter jim zapovida da ju ne dopuste

Nigdare izajti iz pustinje puste. (s. 323-328)

\section{Izkazanje}

Jošter se pak hudi na nju ne smilova tako naruženu i jošter silova,

pak ju i najposli u lugu ostavi i stražu veliku nad njom jošt postavi,

pak jim zapovida da joj ne dopuste iz luga izajti, iz pustinje puste. (s. 213-218) 


\section{Historija}

“O, zale, nečiste, proklete hudobe,

Ne žene, da psice, ljute, nepodobne!” (s. 691-692)

Izkazanje

"O, zale, nečiste, proklete hudobe, ne žene, da kučke, ljute, nepodobne!" (s. 419-420)

\section{Historija}

Filomenu bozi slavićem stvoriše

Ter mnogo sladak glas dati mu hotiše,

Začbo govoriti ona ne mogaše,

Zato slatko perje slaviću podaše. (s. 749-752)

\section{Izkazanje}

Filomenu bozi slavićem stvoriše

i mlogo glas sladak dati mu hotiše,

jerbo govoriti ona ne mogaše,

zato slatki jezik slaviću dadoše. (s. 471-474)

\section{Historija}

A zač biše meso on sinka svoga jil

Ter svojim životom tuko nepošten bil,

Daše mu da bude vazda karvi jisti

Ter gnus človičanski i jine nečisti. (s. 763-766)

\section{Izkazanje}

I jer biše meso sinka svoga jio

i u svomu žitku rodoskvrnjac bio,

bozi njemu daše vazda krvi jisti

i gnjus čovičanski i druge nečisti. (s. 485-488)

Već se iz omjera stihova vidi da je Slavonac mnoge dijelove izostavio, a zašto je to činio, možemo samo nagađati: možda je morao voditi računa o opsegu kalendara, pa je ta tehnička okolnost utjecala i na duljinu spjeva, a možda je jednostavno želio zgusnuti naraciju. Tko ne poznaje Historiju od Filomene i ne zna da je u kalendaru tiskana verzija toga spjeva, neće osjetiti 
da u priči štogod manjka - jer je slavonski priređivač izostavljao dijelove koji nisu presudni, odnosno ne utječu na smisao priče. No ono što je Bogdanović predbacio Ivanu Zadraninu, još više dolazi do izražaja u slavonskoj verziji. Doista, neki su dijelovi nevažni za tijek zbivanja, no važni su za psihološku karakterizaciju lika. Dva je takva odulja paragrafa slavonski priređivač što izostavio, što skratio i preoblikovao, a ni u jednom nije riječ o radnji, nego stanju likova.

Kad Tereo prvi put ugleda Filomenu, počne "goriti", a kad otac oklijeva hoće li ju poslati na put, nagovara ga ona, ali i Tereo, bojeći se da bi otac možda mogao zapriječiti Filomenino putovanje. Zato ga "prizloćudno prosi", himbeno plače, a kad Pandijan pristane, Tereo se zaklinje bogovima da će ju vratiti natrag. Nakon toga uslijedi za Tereja besana noć jer ne može dočekati da krene na put i ispuni svoju "hudu volju". Sutradan Pandijan ponovno dvoji, obraća se Filomeni pa Tereju pa opet Filomeni te se konačnu rastanu. U slavonskoj verziji sve se to događa u kontinuitetu, a opis Terejeve nesanice u Izkazanju je izostavljen:

Dokle oni tako skupa govoriše,

Vrime jure prišlo večerati biše,

Bi jizbin razlicih i s pripravom mnogo,

Ambrozija (nehtar), ka se daje bogom.

Kad bi po večeri, pojdoše svi spati,

Životu i misli prudni pokoj dati.

Tereo usnuti ne more po svu noć

Zač m' u serci biše lipe strilice moć.

Kako luč goreći gorko uzdihaše

Cića Filomene ka tim ne hajaše,

Tisućkrat pogleda k funestri u staklo

Hoteći vidjeti je l' sunce izteklo.

I tako jur veće ležati ne more,

Sta se i opravi vele prija zore.

Poče simo-tamo po kući hoditi

Ter svoje mornare sam poča buditi:

"Ustanite gori ter jadra vežite

I sidra velika gori potežite."

A sam tudje kako sunašce izteče,

Pojde u komori tastu svomu, reče:

"Jure su mornari većkrat dohodili,

Vrime nam je lipo, tja bismo hodili

Zač nam ne bi dobro vrime upustiti,

Zato Filomenu hoti' nam pustiti." 
Pandijan zle volje to onda činjaše

Da nišće ne manje jino ne mogaše

Pokle jur obećal Filomenu biše,

Zato učiniti jinako ne htiše. (s. 127-154)

U Izkazanju je Pandijanovo obraćanje Filomeni - koje u Historiji slijedi nakon navedenih stihova - nadovezano međutim na prvo Terejevo obećanje da će ju vratiti, no slavonski ga je priređivač skratio i preoblikovao:

\section{Historija}

Zato Filomenu dozvavši v komoru,

Reče: "Hćerce mila, sliši ča ti govoru,

Danu sad pogledaj hćerce na ma lita

Ter htij pomisliti da s' karv plemenita.

Ti znaš da veselje starost moja nima

Ni brez tebe radost sarce mi prijima.

Zato spomeni se vreda opet dojti

Ako me žalosti ter tuzi ne ć' biti,

Jer ako te dugo ja budu želiti,

Starost moja ne će živa moći biti.

Ne htij da te želim, ma hćerce, u tuzi,

Ne htij moju starost daržati u uzi." (s. 155-165)

\section{Izkazanje}

Pandijan tad plačuć Filomeni reče:

"Slišaj što besidim, moja mila kćere!

Ti znaš da veselje starost moja nejma, nit brez tebe radost srce moje prima,

zato spomeni se skoro opet dojti jer ću od žalosti s ovog svita pojti.

Nemoj da te želim, mâ kćerce, u tuzi, nemoj moju starost držati u suzi!" (s. 87-94)

U Historiji se Pandijan zatim obraća Tereju (s. 167-178), upućuje pozdrave Pronji i unuku Hitisu (s. 179-180) pa se opet obraća Filomeni (s. 181-188), a zatim se rastaju; Tereo - kojemu se čini da sve traje "tisuć let" - razvija jedra i odlazi (s. 189-198). Slavonski priređivač cio taj dio skraćuje: izostavlja dio Pandijanova obraćanja Tereju (s. 167-172), iza njega smješta Pandijanovo obraćanje Filomeni, a iza njega dio Pandijanova obraćanja Tereju, koji je u Historiji prethodio očevu obraćanju kćeri. Rastanak je opisan 
četirima stihovima koje je slavonski priređivač uzeo s različitih mjesta (u Historiji su to stihovi 179-180, 189 i 197). Taj je dio u Izkazanju oblikovan ovako:

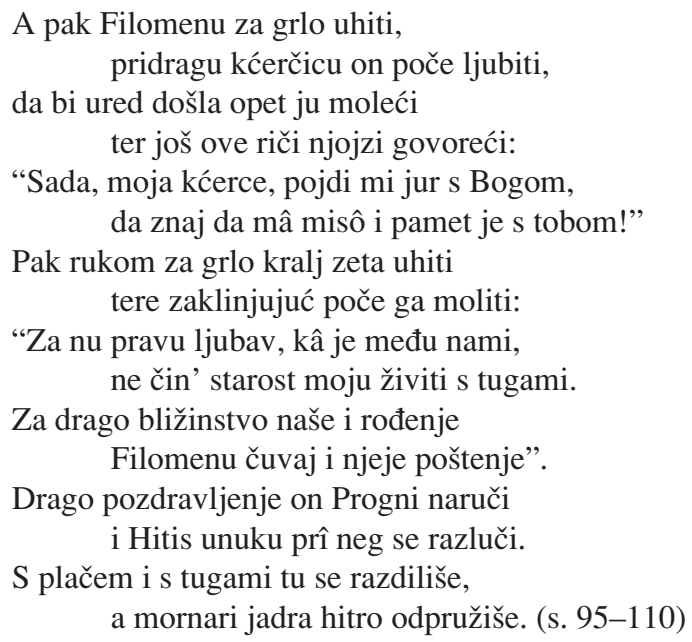

Nedvojbeno se priređivaču učinilo da se u ulomku mnogo razgovara pa je te dionice reducirao. Ipak, opis Terejeve besane noći i opširnija Pandijanova obraćanja kćeri i Tereju imaju u fabuli svoju zadaću: Terejevo grozničavo očekivanje jutra ocrtava jačinu njegove žudnje za Filomenom - što će se poslije podcrtati napomenom da mu se činilo da sve skupa traje tisuću godina, a riječ je o dva dana - pa je trenutak silovanja nesretne Filomene pripremljen i ne čini se da je do njega došlo naglo i nemotivirano. S druge strane u višeputnim Pandijanovim monološkim obraćanjima ocrtana je očeva nježnost prema kćeri, no ima u njima i neke zloguke slutnje; upravo odugovlačenje, pa čak i emocionalno ucjenjivanje Filomene - otac se poziva na svoje godine - čine Filomeninu sudbinu tragičnom. Svega je toga u slavonskom spjevu izostalo: priređivač je naraciju maksimalno funkcionalizirao, razmišljajući zacijelo o čitateljima kalendara, koji se neće pretjerano zanimati motivima i psihološkim karakteristikama likova, nego će ih ponajprije zaokupiti dinamična, nadasve šokantna priča.

Prognina osveta Tereju središnji je dio spjeva, to je najpotresniji, ali i najbizarniji dio priče. Čitatelj je - kolokvijalno kazano - skamenjen od užasa dok čita opis Prognina monstruoznog čina, komadanje još toploga Hitisova tijela izaziva odvratnost i gađenje. Svi su likovi zapravo psihopato- 
loški slučajevi: Terej ne samo da višeputno siluje Filomenu nego joj i reže jezik; Progna ne samo da ubija sina nego ga komada, zatim kuha i peče pa posluži suprugu kao jelo; Filomena ne samo da djetetu odsijeca glavu nego ju s velikim veseljem odnosi Tereju (pritom su joj ruke krvave, a "iz glave friška krv teciše"). Nijedan od tih likova ne može pobuditi sažaljenje, a nakaradnost Prognine i Filomenine zamisli potire smisao odmazde Tereju. Odjednom, čitatelj više ne zna na čiju bi se stranu svrstao: $u$ jednom je trenutku Tereo bio po svemu negativan lik, vrijedan kažnjavanja; nakon što su sestre smislile i provele kaznu, on to više nije.

Ipak Ovidije je - a s njim i Ivan Zadranin - u taj koloplet mračnih strasti unio emocije. Naime kad Progna odluči kazniti Tereja tako što će umoriti njihova sina, ona na trenutak oklijeva jer ju - prirodno-obuzimaju majčinske emocije:

Ali kad bliže pristupi sin i pozdravi majku I vrat joj rukama malim privuče k sebi i počne Poljupce pom'ješane s umiljanjem djetinjskim sipat, Nato se gane majka, i srdžba joj oslabi, stane, Suze joj silom poteku i nehote nakvase oči;

Al' čim od prevelike od ljubavi osjeti, da joj

Srce se ljulja, od njeg okrenula opet se k sestri,

Pa sad gledajuć jedno, sad drugo progovori Progna:

"Zašto se umilja jedan, a druga bez jezika šuti?

Ovaj kad zove me majkom, što ova me sestrom ne zove?

Gledaj, Pandìona kćeri, za kakvog si udata muža!

Postaješ izrod! ta muža ko Terej zločin je ljubit!" (s. 624-635) ${ }^{10}$

U Historiji od Filomene taj je dio ispripovijedan ovako:

Da kada ditićak njoj v krilo priteče,

Za garlo rukami obujamši reče:

"Majko moja draga, majko moja mila,

Kamo si noćaska prez mene hodila?"

Kad Pronje sliša materju se zvati

(To svaki dobro zna ka se zove mati),

Poča se gibati sarce kamenito

Milosardjum k sinu, znajte stanovito.

Preko volje njeje akoprem ne htiše

Da kako jedan daž suze ju poliše.

10 Nazon 1998: 160. 
Poče joj mehčati sarce kamenito,

Ko biše toliko moćno jidovito.

Tuko sarce biše vas jid jur pustilo,

Sinka jedinoga biše joj jur milo.

Da kad opet v obraz sestricu pogljeda,

Sarce joj milosti sebi mesta ne da.

Poča najpri njega, a pak nju gljedati,

Koga bi jimila veće žalovati.

reče: "Ov me dragom majkom svojom zove

Da ga pomiluju, da gljedaj pak ove

Ka reći 'sestrice' jednokrat ne more.

Misli pak sramotu ča je jošće gore,

Ka je učinjena kralju Pandijanu,

Misli jošće pravu veru moju danu,

Ku sam ja Tereju hudomu nosila

Ter ljubav jistinu kon sam ga ljubila.

A on me pogardi i oca još moga,

Kralja Pandijana tere tasta svoga.

Misli sad, nebogo, ča ću učiniti,

Za koga s' oddana, ča ti je viditi.

A sada ako si karvi plemenite

I kuće kraljeve tukoj poglavite,

Ukaži po taj put da se bude znati

Dočim svit ter ljudi budu s njim durati." (s. 559-592)

Priređivač slavonskoga kalendara taj je dio izostavio, i to je najveća intervencija u predložak: dotad je ispuštao uglavnom između dva do deset stihova, ovaj put čak trideset četiri stiha. U Izkazanju Progna odmah naum ostvaruje, nema trenutka dvojbe, nema majčinskih emocija. To je, dakako, uvelike utjecalo na profil toga lika. I dok kod Ovidija, a zatim i u Historiji od Filomene, Progna nije lišena ljudskih osobina, u Izkazanju ih ne posjeduje, faza dolora kod nje izostaje, iz furora odmah upada u nefas. Dok ekonomiziranje u dijelu spjeva koji govori o Pandijanovoj žalosti i Terejevoj nestrpljivosti da se što prije dočepa Filomenina djevičanstva ipak nije bitno utjecalo na koncepciju likova i njihove odnose, izostavljanje trideset četiri stiha bacilo je sasvim drukčije svjetlo na Prognin lik - jer u Izkazanju između Prognine odluke i realizacije nema prostora oklijevanja:

Kraljica ga vidi tako k seb' hodeći

pak reče u sebi, na njega gledeći:

“Aj, kako s' podoban Tereju hudomu, psini nevirnomu te baš otcu tvomu! 
Gledaj njegov obraz, njegovo hodenje, gledaj njegov pogled, gledaj govorenje!

Ti ćeš plaća biti materi sad tvojoj, ti meni osveta i sestrici mojoj, ti ćeš misto otca podnesti pokoru, koju budem znala i mogla najgorju.

Ti više odsele nećeš govoriti”, odluči djetića svoga umoriti.

Kako Hitis dojde, odma ga popade, s njega ruse vlase, obi ruke klade,

poče s njim po kući i po tle mlatiti, hoteći za žalost njime naplatiti.

Brez svake milosti ona njim micaše, srdito i strašno ona ga gledaše,

djetešce vapije, prijamši ručice:

"Ajme, majko mila, ah, majko kraljice!

Majko moja draga!", gorko vapijući.

Ona ga micaše za vlase vukući,

tada tužni Hitis od straha trepetaše, rukami za grlo majki se hitaše,

nje ruke krvave slatko celivaše, koje vrućom krvju svojom polivaše.

Tad mati, ne mati nego kučka, zgrabi, brez svake milosti livi bok mu rani,

ranjen na tle pade ter poče vapiti:

“O, majko, o, majko!", poče govoriti.

Rič pako poslidnju on sasvim ne izusti,

"Majka" htiše reći, a dušicu pusti.

Filomena k njemu onamo pristupi, glavicu odriza, o stinu ju šupi.

Tako pak obedvi brez svake milosti njega razrizaše od kosti do kosti,

svako udo one tude razdiliše, jošter sasvim mrtav Hitišić ne biše.

Tako razdilivši k vatri ponesoše, štogodir kuhati, što peći vrgoše. (s. 353-392)

Premda se u Historiji i Izkazanju priča razvija na isti način, premda su svi likovi u konačnici bezdušni, u Historiji je ipak ostavljeno nešto prostora za empatiju, što je, uostalom, naglašeno stihom "To svaki dobro zna ka se zove mati”. U Izkazanju je međutim dokinuta mogućnost identifikacije s bilo kojim likom. Slavonski priređivač od samog početka skraćuje predložak, no nigdje ispuštanje stihova nije imalo tako radikalne učinke kao na rečenom 
mjestu, upravo zato što je time dokinuto i ono malo čovječnosti koja se u priči mogla naći. Možda je to Slavonac učinio zato što je računao da će jezovitost prizora komadanja nevina djeteta izazvati kod prostodušnih čitatelja najjače učinke? Možda su nevjerica i snebivanje kakve takvi prizori jedino mogu izazvati bile važnije od psihološkog produbljivanja lika? Takvu pretpostavku mogao bi potkrijepiti jedan sitan detalj kojega u Ovidija nema, a nema ga ni u Historiji od Filemene. Naime ovako je u Metamorfozama i u čakavskom spjevu opisan trenutak ubojstva djeteta:

\section{Metamorfoze}

Mahom Itisa ščepa na tigra od Ganga nalik,

Koji ugrabi lane, još sisavče, u šumi hladnoj.

I u zabitni dio kod visokih dvorova dođu,

Itis pružajuć ruke i svoju već videć sudbinu

Viče: "Majko! o majko" i hvata je za vrat, al' Progna

Mačem ga udari tamo, gdje prsi se sastaju s bokom,

I ne odvrati lica, a Itisu dosta i jedna

Rana je za smrt, a mačem pres'ječe mu vrat Filomela.

Ude još žive i s nešto još duše rastrgnu one,

I dio jedan ih vri u prostranom kotlu, a drugi

Dio cvrči na ražnju, a krvlju su oblite sobe. (s. 636-646)

\section{Historija}

Tako ga privuče v mesto najskrovito

Koj' v kraljevi biše kući stanovito.

Tada tužni Hitis za strah trepetaše,

Rukami za grlo majci se hitaše.

Nje ruke krvave slatko celivaše,

Ke joj s vrućom karvju svojom polivaše.

Tad mati, ne mati, psica, veruj mani,

Brez svake milosti livi bok mu rani,

jednim britkim mačem brez svake milosti.

$\mathrm{Ni}$ za to ukaza nijedne radosti,

Ni oči ni obraz na stranu ne ganu,

Ni sarce krudelo kad mu poda ranu.

Ranjen na tla pade ter poča vapiti:

"Oh, majko, oh, majko", poča govoriti

Onako u karvi jur vas koporući.

Li majku zoviše željno dite mrući

Ter napokonju rič ku sasvim ne zusti:

'Majko' htiše reći, a dušicu pusti. 
Filomena k njemu onamo pristupi

Da svoju sramotu Tereju tad skupi.

Tad jedan ostar nož u ruke vazamši,

Glavicu odriza za vlas ju jamši.

Tako pak obidvi brez svake milosti

Jaše ga rizati od kosti do kosti.

Svaki ud posebi tudje razdiliše,

Jošče sasvim martav ditićak ne biše.

Tako razdilivši k ognju ponesoše,

Nič jaše kuhati, nič peći vargoše.

Još mu se gibahu u ručicah pulsi

Kada naticahu na ražanj ti kusi. (s. 605-634)

Odmah upada u oči da je pjesnik Historije uvelike proširio brutalnu scenu, napunio ju detaljima kojih kod Ovidija nema, potanko opisujući kako su razjarene žene dječaka ne komadale nego "rizale". Koliko god sama pomisao na takav čin bila strašna, pjesnik se potrudio da bude još strašnija upravo zbog opisivanja praktične strane posla. Slavonski je priređivač neke stihove iz Historije izostavio (s. 605-606, 613-616, 619-620, 624-625, 633-634), no dodao je nešto svoje: u tiskanom se spjevu naime kaže da Filomena Hitisu "glavicu odriza za vlas ju jamši”, u Izkazanju "glavicu odriza, o stinu ju šupi”. Ta naoko nevažna preinaka, mislim, ponešto govori o motivima koji su slavonskog prevoditelja vodili kad je u predlošku dijelove ispuštao, premještao ili ih sažimao. Riječ je o onome što Divna Zečević naziva glađu za senzacijom, za iznimnošću ispripovijedanog događaja, za animalnim i sirovim strastima koje izlaze izvan svakog okvira racionalnog doživljavanja svijeta. Slavonski je priređivač znao da su takvi prizori odbojni, ali da će čitatelje kalendara upravo oni dojmiti. Zato valjda nije bilo dovoljno da Filomena dječaku odreže glavu, nego je k tomu još morala njome udariti o stijenu, u čemu nema ničeg drugog doli ničemu prispodobive svireposti.

Priča o Filomeni idealan je materijal za pučko štivo: nasilno oduzimanje djevičanstva s kojim je skopčano ubojstvo. No ne bilo kakvo ubojstvo nije to ni patricid ni matricid - nego ubojstvo djeteta. U hrvatskoj ranonovovjekovnoj književnosti samo se jedanput dogodilo - prije Historije od Filomene - da se usmrćuju djeca: u tragediji Saba Gučetića Bendeviševića (oko 1531-1603) Dalida otac glavne junakinje, kralj Atrij, raskomada unuke i pokaže ih na pladnju kćeri, nakon čega Dalida poludi, ubije oca pa sebe. Ipak ubojstva koja su bila karakteristična za senekijansku tragediju nisu se prikazivala na sceni, a nisu se ni potanko opisivala. Ta je tabuizirana tema 
prvi put utjelovljena u ekstenzivnom opisu u Historiji od Filomene. Nema u tome nikakve ljepote, pa ipak je pjesnik znao zbog čega obrađuje upravo tu metamorfozu, znao je zašto na rečenom mjestu širi Ovidijev predložak. Računao je na specifičan čitateljski ukus, potrebu zgražanja nad nečovječnim postupcima. Pred tim su blijedjele sve nelogičnosti u priči (primjerice kako to da se Filomena tek nakon deset godina domislila na tkanini navesti svoj udes), pred tim se povlačila svaka potreba stvaranja kakve zahtjevnije figure, ostajao je tek pročišćeni užas kao glavni razlog pričanja priče. Ne treba čuditi da se nakon Brogiollieve smrti zateklo čak tisuću primjeraka Historije od Filomene - koliko ih je prije toga prodao, ne znamo - kao što ne treba čuditi da je Occhi, neovisno o tolikom broju primjeraka koje je od Brogiollia naslijedio, poslije tiskao i prodavao i svoje izdanje. ${ }^{11}$ Jednostavno: Historija od Filomene bila je bestseler.

Budući da je potvrđena u hrvatskoj usmenoj predaji ${ }^{12}$ čudilo bi da se ta priča nije pretvorila u kalendarsko štivo. Manje sam sklon pomišljati da je u slavonski kalendar za 1786. godinu ušla zato što je bila riječ o djelu koje je "na svitlo dao" pripadnik Reda male braće - kalendare u Slavoniji 18. stoljeća priređivali su franjevci - a više zato što je riječ o priči sasvim udešenoj prema pučkom ukusu. Doduše, sličnih sastavaka nisam našao u slavonskim kalendarima: pjesmama iz Kačićeve pjesmarice rijetko je što moglo konkurirati, pazili su Slavonci da im kalendari budu opskrbljeni zabavnim i poučnim tekstovima kraćeg daha, kadšto nabožnim pjesmama. U priči o Filomeni sve je brutalno, pjesnik ju nije prekodirao u sustav kršćanske moralke, pa u tom smislu čitatelju nije mogla ponuditi nešto povrh zaprepašćujuće fabule, napunjene krvoločnim detaljima. Spjev o Filomeni ne govori o slavnoj prošlosti, o narodnim junacima, nije smiješan, a ne nudi ni koju transparentniju moralnu pouku. Kako je već rečeno, zabavnost se

11 Occhi je knjigu navodio na popisima koje je tiskao uz Suze sina razmetnoga (1703) Ivana Gundulića, Život svete Katarine (1709) Matije Divkovića (1563-1631) i Cvijet od kriposti (1712) Pavla Posilovića (između 1597. i 1598-1657). Koštala je 6 soldi i spadala među jeftinije knjige; primjerice, Robinja Hanibala Lucića (1485-1553) stajala je 16 soldi.

12 Godine 1887. zabilježio je Krsto Pavletić u Bakru pjesmu koju mu je kazivala Josipa Medanić, nepismena "podvorkinja u brzojavnom uredu". Pisao je o tome u nastavcima u radu Grčka priča o Prokni i Filomeli kod Hrvata (1894a: 320-323, 1894b: 333-335, 1894c: 349-351, 1894d: 362-366). Smatrao je da "pjesma ova ne će biti jako stara, a sigurno je k nama došla iz Italije" (1894d: 364), s čim se nije slagao David Bogdanović, smatrajući da je "hrvatska narodna kancona potekla iz Ovidijeve metamorfoze i da je upravo preko njene hrvatske prerade, preko historije fra Ivana od Zadra prešla u narodno pričanje i narodnu pjesmu" (1928b: 92). 
krije drugdje: u jezovitoj priči, zbog čega se "kod Ovidijeva štiva moramo oboružati sa željeznim očima, da gledamo, gdje se u mjedenom kotlu vrutkom prevrće i na ražnju cičeći peče Itisovo meso" (Pavletić 1894d: 363). U hrvatskoj obradi baš se u tom dijelu rasplamsala piščeva mašta, a ponešto je detalja pridometnuo i slavonski priređivač. Bio je to, kako mislim, fra Marijan Lanosović (1742-1812), profesor filozofije i teologije, autor dviju gramatika (Tatarin 2013: 44-48).

\section{LITERATURA}

B-ć, J. 1928. Rijetka knjiga: Ovidijeva metamorfoza u hrvatskoj preradi g. 1602. "Književnik", I, 4: 147-148.

Bogdanović, David. 1928a. Fra Ivana od Zadra "Historija od Filomene". "Nastavni vjesnik", XXXVII, 2: 56-69.

Bogdanović, David. 1928b. Fra Ivana od Zadra "Historija od Filomene". "Nastavni vjesnik", XXXVII, 3: 89-93.

Bošković-Stulli, Maja i Divna Zečević. 1978. Usmena i pučka književnost. Povijest hrvatske književnosti, knjiga 3. Zagreb: Liber - Mladost.

Deanović, Mirko. 1912. "Filomena" tragedija nepoznatog autora. "Nastavni vjesnik", XX, 10: 688-696.

Frkin, Vatroslav i Miljenko Holzleitner. 2008. Bibliografiji knjiga hrvatskih autora u knjižnicama Hrvatske franjevačke provincije sv. Ćirila i Metoda 1495. - 1850. Zagreb: Hrvatska akademija znanosti i umjetnosti - Hrvatska franjevačka provincija sv. Ćirila i Metoda.

Kapetanović, Amir. 2003. Jezične značajke i leksikografska obrada fra Ivanove Filomene iz XVII. stoljeća. "Rasprave Instituta za hrvatski jezik i jezikoslovlje", 29: 131-155.

Kapetanović, Amir. 2004. "Historija od Filomene" fra Ivana od Zadra. "Hrvatska književna baština", 3: 277-309.

Kolendić, Petar. 1964. Filomena, dubrovačka tragedija XVII veka. Iz staroga Dubrovnika. Priredio Miroslav Pantić. Beograd: Srpska književna zadruga, 203-207.

Kolumbić, Nikica. 2005. Ivan Zadranin (Ivan od Zadra). Hrvatski biografski leksikon 6 (I - Kal). Zagreb: Leksikografski zavod Miroslav Krleža, 102.

Lisac, Josip. 2015. Ivan Šiško Gundulić: Filomena. “Zadarska smotra”, LXIV, 4: 79-120.

Nazon, Publije Ovidije. 1998. Publija Ovidija Nasona Metamorfoze. Preveo T. Maretić. Velika Gorica: Nakladnik Papir.

Pavletić, Krsto. 1894a. Grčka priča o Prokni i Filomeli kod Hrvata. "Vienac", XXVI, 20: 320-323.

Pavletić, Krsto. 1894b. Grčka priča o Prokni i Filomeli kod Hrvata. "Vienac", XXVI, 21: 333-335.

Pavletić, Krsto. 1894c. Grčka priča o Prokni i Filomeli kod Hrvata. "Vienac", XXVI, 22: $349-351$. 
Pavletić, Krsto. 1894d. Grčka priča o Prokni i Filomeli kod Hrvata. "Vienac", XXVI, 23: 362-366.

Pavličić, Pavao. 1998. Ignjat Alojzije Brlić izdaje Palmotićevu Kristijadu. Dani Hvarskog kazališta XXIV (Hrvatska književnost u doba preporoda - ilirizam, romantizam). Split: Književni krug, 172-192.

Rječnik hrvatskoga ili srpskoga jezika, dio III. 1887-1891. Zagreb: Jugoslavenska akademija znanosti i umjetnosti.

Stipčević, Aleksandar. 2008. Hrvatske knjige u inventaru mletačkog tiskara i knjižara F. Brogiollija iz 1678. god. "Croatica et Slavica Iadertina”, IV: 279-308.

Švelec, Franjo. 1994. O adespotnim stihovanim sastavima zadarskoga književnog kruga u XVII. stoljeću. Dani Hvarskog kazališta XX (Hrvatsko barokno pjesništvo - Dubrovnik i dalmatinske komune). Split: Književni krug, 124-140.

Tatarin, Milovan. 1999. Ponovljena izdanja spjeva o Olivi u 19. stoljeću. Zaboravljena Oliva: rasprave o hrvatskoj nabožnoj književnosti 18. stoljeća. Zagreb: Matica hrvatska, 132-188.

Tatarin, Milovan. 2006a. Uloga pučkih kalendara u stvaranju hrvatske čitateljske publike (Kalendar Ignjata Alojzija Brlića). Raslojavanje jezika i književnosti, Zbornik radova 34. seminara Zagrebačke slavističke škole. Zagreb: FF press, 107-141.

Tatarin, Milovan. 2006b. "Priobrazna pisma" o Piramu i Tizbi u kalendaru Antuna Nagya, "slavonskoga Ovidije”. "Osmišljavanja” : zbornik u čast 80. rođendana akademika Miroslava Šicela. Priredio Vinko Brešić. Zagreb: FF press, 87-111.

Tatarin, Milovan, 2007. Hagiografski spjev o svetoj Olivi Antuna Josipa Knezovića. Ljubavi nebeske, ljubavi zemaljske: prilozi hrvatskoj nabožnoj književnosti 18. stoljeća. Zagreb: Disput, 107-209.

Tatarin, Milovan. 2013. Jedna slavonska svjetovna drama tiskana u 18. stoljeću. "Croatica", 57: 39-71.

\section{SUMMARY}

\section{SLAVONIAN VERSION OF THE 1786 EPIC POEM ON PHILOMELA}

The only literary text published in the New and Old Illyric Calendar for the year 1786 was the epic poem The Story of Philomena, Daughter of King Pandian. It is a story about Philomela, Procne and Tereus as told in Book Six of Ovid's Metamorphoses. The Calendar's editor, however, used The History of Philomena, Daughter of King Pandion by Fra Ivan of Zadar as a source whereby he translated Fra Ivan's Chakavian text into Ikavian Shtokavian. In the process of translation, the editor has left out many parts of the source text, summarized and changed certain parts and, occasionally, even added new verses.

Keywords: $18^{\text {th }}$ century Slavonian literature, almanac, Ovid, Philomela, Ivan of Zadar, Marijan Lanosović 